\title{
'n Godsleer van Openbaring soos vervat in die himnes
}

E Meyer

(UP)

\section{ABSTRACT}

\section{A Theology of Revelations as imbedded in the hymns}

This article is based on a twofold hypothesis, namely that the author of Revelation not only wrote the hymns in this book; he also used them specifically to express his theology. The narrator utilises the hymnes to lay words in the mouths of the characters in order to establish a complete theology as well as christology. These hymns can even be used today to offer mankind real hope by calling one and all to the centre and true reason for our existence: Worship God!

\section{PROBLEEMSTELLING}

Smelik ${ }^{1}$ wys daarop dat die verteltegniek van die Bybel-skrywers in sekere opsigte radikaal van hedendaagse tegnieke verskil. Bybelskrywers lewer gewoonlik nie direkte kommentaar by gebeurtenisse en belewenisse in 'n narratief of verhaal nie, maar laat dit aan die leser/hoorder oor om sy/haar eie gevolgtrekkings te makk. By wyse van 'n poëtiese teks word die skrywer egter die geleentheid gebied om die (hoof)karakter woorde in die mond te lê. Dit stel die verteller daartoe in staat om kommentaar op die teks te lewer. Die skrywer van Openbaring het dan ook bepaalde himnes met 'n spesifieke doel voor oë in sy teks verweef. Hierdie artikel het dan ook ten doel om aan te toon hoedanig die skrywer van Openbaring die himnes aanwend om sy Godsleer te verwoord deur middel van die lofprysing en aanbidding, wat daar in die hemel aan God toegesing word.

Ek gaan van die standpunt uit van teoloë soos Carnegie ${ }^{2}$ en Aune $^{3}$, naamlik dat die liedere, wat in Openbaring 4, 5, 7, 11, 15 en 19 voorkom, telkens ten nouste met die konteks verweef is en dus nouliks uit 'n ander konteks geneem kon gewees het. Die liedere in Openbaring is waarskynlik deur die outeur self geskryf aangesien die verskillende liedere in Openbaring dieselfde woordeskat bevat en in dieselfde styl geskryf is as die res van die boek. Om hierdie stelling verder te illustreer toon Carnegie ${ }^{4}$ aan dat dieselfde terminologie ook in die narratiewe gedeeltes van die boek aangetref word, "(like) the use of the divine names both within and outside the hymns". 
Die himnes wat in hierdie studie onder die soeklik gekom het, is deur Carnegie $^{5}$ onderskei as dié himnes in Openbaring, waarin die hemelinge God en die Lam se lof besing. Dit sluit in: Openbaring 4:8(b), 9-11; Openbaring 5:9-10; Openbaring 7:10-12; Openbaring 11:17-18; Openbaring 15:3(b)-4; Openbaring 19:1-8.

'n Himne kan van ander soorte tekste, byvoorbeeld homilieë, evangelies en briewe onderskei word, in dié sin dat die wesenskenmerk van 'n bybelse himne daarop gerig is om God se lof te besing6. Die liedere in Openbaring is duidelik onderskeibaar van die narratiewe gedeeltes.

Resente navorsing het getoon dat die liedere in Openbaring 'n tipies semitiese metriese struktuur vertoon. Dit hou verband met die feit dat hierdie liedere via Joodse antesedente in Joods-Christelike kringe hul ontstaan gehad het en sodoende kom hul metriese struktuur ooreen met ander Ou-Testamentiese en ná-eksiliese himnes in onder andere Daniël?, Henog, Barug en Esra ${ }^{8}$.

Kenmerkend van die himnes in Openbaring is die tweede persoonsaanspreekvorm, bekend as epiklesis Dei of invocatio Dei waardeur die Godheid aangespreek word ${ }^{9}$. Dit word dan ook gedoen by wyse van verskillende titels, byvoorbeeld: "Here, God, Almagtige, U is..." (vgl 11:17; 15:3; 19:6).

'n Derde kenmerk van hierdie liedere is die derde persoons-stylvorm $^{10}$, wat saam met die tweede persoons-aanspreekvorm gebruik word. In talle van die liedere word die heiliges byvoorbeeld opgeroep om God te loof: "Loof ons God, al sy dienaars, die wat Hom vrees, klein en groot..." (Op 19:5).

'n Vierde eienskap van die himnes is die refrein ${ }^{11}$, wat as een van die belangrikste strofiese merkers dien. In die himnes in Openbaring word onder andere gebruik gemaak van die begrippe: "Amen" en "Halleluja" aan die begin en of einde van 'n strofe. Dit dien dan ook as inclusio (Op $7: 10-12 ; 19: 4)$. Soms word sulke begrippe ook as losstaande eenhede in strofes aangetref.

In 'n doksologie is die belangrikste elemente volgens Kroll12 lofprysing, danksegging en aanbidding. Hiervan tref ons talle voorbeelde in die himnes in Openbaring aan, byvoorbeeld:

* Lof:

19:1 "Prys die Here! Die oorwinning, die heerlikheid en die mag behoort aan ons God!" 
* Danksegging: 11:17 “Ons dank U, Here God, Almagtige”.

* Aanbidding: 5:9 " $\mathrm{U}$ is waardig om die boek te neem en die seëls daarvan oop te maak, omdat U geslag is en met u bloed mense vir God losgekoop het uit elke stam en taal en volk en nasie".

'n Sesde kenmerk van die liedere in Openbaring is die exhortatio ${ }^{13}$. Dit tref ons aan in die vermanende en aansporende gedeeltes van die liedere, byvoorbeeld: "Laat ons bly wees en juig en aan Hom die eer gee..." (Op 19:7).

'n Sewende kenmerk van die lied is die belydenis of confessio ${ }^{14}$. In Openbaring vind ons voorbeelde van sulke belydenisse, wat spesifiek daarop gerig is om onder andere die Godheid van Jesus te beklemtoon: "Aan Hom wat op die troon sit en aan die Lam behoort die lof en die eer, die heerlikheid en die krag tot in alle ewigheid" (Op 5:13).

'n Agtste eienskap van die lied word die "heilige verhaal" 15 genoem. Dit definieer die verlossingsdade van God en wel in terme van dramatiese oorvertellings, wat as voorbeelde dien van God se genade, oordeel en verlossing, byvoorbeeld: "Regverdig en reg is sy oordele, want $\mathrm{Hy}$ het die oordeel voltrek oor die sedelose vrou, wat die aarde deur haar onsedelikheid verwoes het. Hy het die dood van sy dienaars op haar gewreek" (Op 19:2).

Verdere kenmerke van liedere, wat ook in Openbaring aangetref word, is:

* Klimaktiese styl:

* Gestolde frases:

* Opeenstapeling van woorde:
Soos in Openbaring 11:17-18, waar daar ook duidelik sprake is van progressie.

Soos in Openbaring 4:8; 11:17, waar God se ewigheidsbestaan uitgedruk word, met behulp van die gestolde frase: "Hy wat is en wat was en wat kom".

Soos in Openbaring 4:8; 15:3; 119:6, waar God benoem word by wyse van 'n opeenstapeling van name: "Here, God, Almagtige". 


\section{3 'N GESISTEMATISEERDE UITEENSETTING VAN DIE GODSLEER VAN OPENBARING SOOS VERVAT IN DIE HIMNES}

Met die studie van die himnes in Openbaring ontvou daar voor die leser 'n toneel, wat beide die geskiedenis en die tydsbegrip in perspektief plaas. Die liedere in Openbaring onthul op aangrypende wyse God se heerlikheid en almag.

Johannes se teosentriese teologie is benewens sy onderskeidende leer aangaande God een van sy belangrikste bydraes tot die Nuwe-Testamentiese teologie ${ }^{16}$. In Openbaring leer ons die Drie-enige God ken (Op 1:4b-5a). Openbaring se briefaanhef is ook uniek aan die Nuwe Testament in terme van die trinitariese karakter daarvan ${ }^{17}$. Hierdie trinitariese uitgangspunt word in die liedere voorveronderstel, al word daar nie direk na die Heilige Gees verwys nie, aangesien Johannes in die narratiewe gedeeltes God, die Lam en die Gees onderskei. 'n Besondere kenmerk van die himnes is dat Jesus se Godheid op spesiale wyse beklemtoon word.

Johannes slaag daarin om sy hoogs teosentriese teologie in sy liedere te vervat. Om die waarheid te sê, die himnes in Openbaring is die draers van Johannes se teologie.

\subsection{Die Godsleer van Openbaring soos vervat in die himnes}

Johannes skilder ' $n$ aangrypende toneel van God in al sy heerlikheid. Daar word op sigbare wyse prominensie verleen aan God se aanbiddingswaardigheid by wyse van die hemelse wesens, wie se hele bestaan daarop gerig is om God te aanbid. By wyse van die himnes word die skrywer van Openbaring daartoe in staat gestel om die hemelse karakters woorde in die mond te lê en om op hierdie wyse teologiese kommentaar te lewer. Die liedere wat in die derde persoonsvorm gesing word, word eintlik aan die verteller van die apokalips gerig, terwyl dit in die teenwoordigheid van God gesing word ${ }^{18}$. Hierdie liedere word funksioneel aangewend om die Godsbeeld in Openbaring saam te vat en te verwoord. Uit die himnes leer ons God soos volg ken:

\subsubsection{God is die Almagtige - Hy is in beheer!}

Die Griekse wêreld van destyds was kosmologies begrond en die antieke Midde-Oosterse mens het die wêreld verstaan in terme van 'n verhouding tussen die mitologie en die natuur ${ }^{19}$. Die Hellenistiese wêreld was gevul met demoniese magte wat beheer uitgeoefen het oor alle menslike 
bestaan ${ }^{20}$. Hierteenoor wil Johannes aantoon dat dit nie die noodlot is wat in beheer is van alles wat gebeur nie, maar God, die Almagtige!

Om God se Naam te verheerlik beteken om Hom te loof, te prys en te aanbid vir wie $\mathrm{Hy}$ is en vir wat $\mathrm{Hy}$ alles gedoen het ${ }^{21}$. God se heiligheid word in Openbaring 4:8(c) deur die vier lewende wesens besing en behoort ook deur die skepping besing te word. Hiermee word aangetoon dat God totaal en al anders is as die skepping en verhewe is bo alle skepsele - $\mathrm{Hy}$ is die Heilige. Op tipies Joodse-, dog unieke wyse word God hier as die $\pi \alpha \nu$ ток $\rho \alpha \tau \omega \rho$ vereer. Johannes skilder hoe die bose magte in hierdie wêreld aan die werk is. God is egter in beheer van alles wat gebeur. Hy bepaal die tydsgrense, maar ook die optrede van die bose en maak laasgenoemde tot voorwerpe van sy oordeel (Op 13:5; 19:2). Daarmee word God se onbeperkte mag en gesag oor alles en almal asook oor die gang van die geskiedenis aangetoon.

God se tydloosheid en sy mag oor die gang van die geskiedenis word luisterryk geillustreer aan die hand van die interpretasie van die Goddelike naam "Jahwe". Enersyds wil Johannes beklemtoon dat God 'n tydlose wese is en andersyds wil hy God se beheer en heerskappy oor die verlede, hede en toekoms beskryf aan die hand van die gestolde uitdrukking: " $\dot{o} \dot{\eta} \nu$

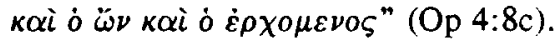

Deur die opeenstapeling van Godsname, wil Johannes ook op godsdienstig-evokatiewe wyse God se bonatuurlike mag, posisie en status aandui. Hy maak op onderskeidende wyse gebruik van die interpretasie van die Godsname te wete:

$\begin{array}{ll}* & \text { Here, } \\ * & \text { God, } \\ * & \text { Almagtige. }\end{array}$

Hiermee beklemtoon Johannes dat daar geen verband tussen die mens en die Skepper of tussen die mens se bestaanswyse en dié van God bestaan nie. Hy is totaal uniek. Hierdie beskrywing van God dien egter ook as vertroosting aan die gelowiges in 'n tyd van beproewing en lyding: God is in beheer. Sy mag en krag is onbeperk. Niks val buite sy beheer nie. Hy is die Almagtige.

Binne die religieus-politieke konteks van destyds het die Romeinse Ryk as politieke mag ook sy gesag in religieuse terme uitgedruk ${ }^{22}$. Dit het daartoe aanleiding gegee dat staatsgodsdiens en keiseraanbidding aan die orde van die dag was. In reaksie hierop wil die himnes in Openbaring ontsluit dat ware aanbidding slegs vir Hom wat op die goddelike, hemelse troon sit, toekom. Daarom word God se waardigheid om alle heerlikheid, eer en mag te ontvang, beklemtoon. Die rede daarvoor word gevind in die 
feit dat God die Skepper is.

God se heerlikheid ( $\delta \dot{\delta} \xi \alpha$ ) word sigbaar in die glansende manifestasie van sy persoon, sy glorieryke openbaring en deur sy dade ${ }^{23}$. Die totaliteit van God se heerskappy word besing by wyse van sy mag

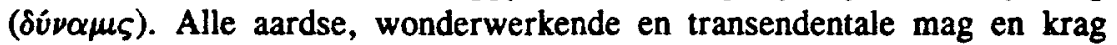
behoort aan God. Die sigbare demonstrasie daarvan kan gesien word in sy skepping.

\subsubsection{God is die Skepper - Hy het alles en almal tot stand gebring!}

Heeltemal anders as mensgemaakte gode is God die onvergelyklike Een, aan wie die ganse skepping en alle skepsele hulle moet onderwerp. God het alle dinge vooraf gegaan en Hy sal ook alles tot 'n eskatologiese vervulling bring, want $\mathrm{Hy}$ is die Skepper ${ }^{24}$.

God se skeppersrol het nie verval nadat Hy die skepping tot stand gebring het nie. Hy is steeds in beheer van sy skepping en sien in liefdevolle trou daarna om. By wyse van die himne van die ouderlinge (Op 4:10) word die geloof in God as die Skepper bevestig, maar word die vertroue ook uitgespreek dat die troue skeppergod ook sy skepping tot voleindiging sal bring by wyse van 'n nuwe skepping, te wete die "nuwe hemel" en "nuwe aarde" (Op 21:1)25.

Die uitbeelding van God as die Skepper volgens wie se wil alles geskape is, vorm die basis van die Judaïsme en ook die Christelike godsdiens. As Skepper het God alles in aansyn geroep en daarom is alles en almal dan ook aan Hom aanbidding verskuldig. God is waardig om al die mag, eer en heerlikheid te ontvang, omdat alles in ooreenstemming met sy wil is en geskape is. Hierdie frase wil aantoon dat alles wat bestaan binne die ewige wil en deur die ewige wil van God ontstaan het en daarom aan sy mag en gesag onderworpe is. Hierdie verstaanswyse van God as die Skepper is nie alleen ' $n$ integrale deel van die Joodse en Christelike monoteïsme nie, maar vorm terselfdertyd ook die basis van die Christelike eskatologie. Indien God die transendente oorsprong van alle dinge is, bestaan daar ook 'n onbeperkte magdom moontlikhede vir die herskepping van sy skepping in die toekoms ${ }^{26}$.

\subsubsection{God is die Redder en Verlosser - Hy bewerk die heil}

Die verlossing van die mensheid was die hoogste doel van God se skepping ${ }^{27}$. Hierdie verlossing het God deur die Lam bewerk. Dit het groot feesvreugde tot gevolg, wanneer die menigte triomferende gelowiges 
volgens Openbaring 7:12 God se lof by wyse van 'n sewevoudige doksologie besing. Hulle loof God vir sy ewige plan van verlossing, wat gerealiseer het deur die dood, opstanding en verheerliking van die Lam. Op grond van God se verlossingsdade word sy lof, heerlikheid, wysheid, dank, eer, mag en sterkte besing. Mounce ${ }^{28}$ vat die betekenis van hierdie eienskappe van God soos volg saam: Lof is die spontane dank wat aan God toegebring word; heerlikheid is die glans en glorie wat daar van God uitgaan; wysheid is die goddelike kennis wat gerealiseer het in die goddelike verlossingsplan; dank is die gepaste antwoord op verlossing; eer is die openbare erkenning van God; mag is God se vermoë om op te tree en om te handel; sterkte is God se verlossende teenwoordigheid in die gang van die geskiedenis.

God is al hierdie eienskappe van lof waardig, omdat Hy die Redder en Verlosser is. Die reddende dade van God, soos vervat in die Eksodustradisie, dien as afskaduwing van 'n groter en heerliker redding, wat deur die Lam bewerk is ${ }^{29}$. Sodoende kulmineer God se dade van redding en oorwinning wat in die tyd van Moses begin het, uiteindelik in die lewe, sterwe, opstanding en oorwinning van die Lam (Op 15:3).

\subsubsection{God is die Regter - Hy oordeel}

Die liedere in Openbaring wil die leser/hoorder daartoe bring om God as die enigste, ware, heilige skeppergod te erken, te aanbid en te dien. Hierdie aanbidding word deur Johannes vanuit hemelse perspektief aan sy lesers voorgehou. Aangesien God se geregtigheid nie in hierdie wêreld tot sy reg kom nie, sal God die wêreld oordeel. Diegene wat die evangelie aangaande Jesus Christus verwerp en hulle nie van hul bose werke bekeer nie en nie vir God as skeppergod aanbid nie, kan nie aanspraak maak op God se genade nie. Hulle val onder die oordeel van God se toorn (Op 6:16; $11: 18 ; 14: 10 ; 16: 9 ; 19: 5)$.

God se heerskappy op grond van die feit dat Hy die Skepper en in Jesus Christus ook die Redder is, gee aan Hom die reg om as Regter op te tree (Op 11:18). Verder hou God se heiligheid ook direk verband met sy oordeel. Vanweë God se heiligheid kan Hy ongeregtigheid nie verdra nie. Daarom word God se absolute heiligheid in sy glorie en mag tydens die finale oordeel geopenbaar ${ }^{30}$.

Hierdie voorstelling van God se opperheerskappy as transendente Heerser en Regter word skerp deur feministiese teoloë veroordeel ${ }^{31}$. Hierdie kritiek spruit uit 'n onvermoë om in te sien en te erken dat die verhouding tussen God en die mens nie op alle vlakke reglynig deurgetrek 
kan word na aardse verhoudinge nie. Alle voorstellings van God kan nie sondermeer as modelle vir menslike gedrag dien nie. God is as ewige, heilige, transendentale bestaanswyse verhewe bo sy skepping en alle skepsele en oordeel dus alles wat $\mathrm{Hy}$ geskape het op grond van reg en geregtigheid: "These designations for God are also notably nonanthropomorfic, suggesting that God's relation to the world transcends human analogies" 32 .

God laat geen menslike opstand sondermeer verbygaan nie, aangesien dit aanvalle op sy mag en outoriteit impliseer. Daarom straf Hy die woede van die nasies (Op 11:17-18). God se wraak is nie irrasioneel nie, maar die gepaste antwoord op die opstand van die mensdom ${ }^{33}$. Verder is die vernietigers van die aarde, naamlik die bose magte, die draak, die dier en die sedelose vrou almal voorwerpe van God se oordeel: "(God's) faithfulness to his creation requires that he destroys them in order to preserve and deliver it from evil" 34 .

God se oordeel hou egter meer as straf in. Dit verseker ook beloning vir diegene wat dit verdien (Op 11:18d). Die gelowiges of heiliges asook al God se profete en dienaars kan op grond van die feit dat hulle klere in die bloed van die Lam gewas is (Op 7:14), aanspraak maak op God se ryke beloftes van oorwinning en ewige vreugde.

\subsubsection{God is die Koning - Hy heers}

Wanneer Johannes vir God in sy troonkamer skilder (Op 4:1-11), dien dit as voorbeeld van politieke simboliek om God se heerskappy en regering oor die wêreld uit te beeld ${ }^{35}$. Dit is vir Johannes se lesers noodsaaklik om by wyse van hierdie troonvisioen te sien dat dit God is wat in beheer is, al wil dit voorkom asof die Romeinse Ryk die heerserstaf swaai. Die troon dien as simbool van God se hemelse mag en transendente majesteit ${ }^{36}$. Hierdeur wil Johannes aantoon dat wanneer God se heerskappy ook op aarde deurbreek soos wat dit alreeds in die hemel die geval is, dit die gewaande Romeinse mag totaal en al sal vervang en oorskadu: "What is true in heaven must become true on earth... heaven is the sphere of ultimate reality" 37 .

Openbaring 15:3(b)-4 eggo 'n lied wat elke Sabbat in die sinagoge gesing is om God as koning te besing en om Hom te dank vir sy verlossingsdade 38: "Wie is soos $\mathrm{U}$, so hoog geëer en heilig, gedug in roemryke dade, een wat wonders doen?" (Eks 15:11).

God is in beheer en Hy was altyd in beheer. Hy het nie sy heerskappy afgegee om dit weer op te neem in Openbaring 11:17 nie. Inteendeel, 
Openbaring 11 wil aantoon dat God alle rebellie teen sy gesag uitwis en sy mag en gesag sigbaar gevestig het sodat dit deur almal erken kan word. God se heerskappy het finaal en sigbaar deurgebreek in Jesus Christus.

Die Joodse messiasverwagting het onder andere ook 'n verwagting ingesluit dat God as die universele heerser erken sal word ${ }^{39}$. Nadat die magte van die bose vernietig is, word God finaal as koning erken: "Die koningskap oor die wêreld behoort aan ons Here en aan sy Gesalfde, en Hy sal as koning heers tot in alle ewigheid" (Op 11:15). God se koningskap sal sigbaar gevier word met die bruilof van die $\mathrm{Lam}^{40}$.

\subsubsection{God is die unieke en ware God - Hy moet aanbid word}

Ware kennis van God lei noodwendig tot aanbidding van God. Die ononderbroke aanbidding deur die vier lewende wesens rondom die troon van God (Op 4:8; 19:4) is die sentrum en hartklop van alle bestaan. Hulle aanbidding verteenwoordig die teosentriese aard van die totale werklikheid, wat uiteindelik in die aanbidding van God sy volvoering vind ${ }^{41}$. Hulle prys God vir wie $\mathrm{Hy}$ is (Op 4:8).

Rondom God se troon staan daar vier en twintig trone waarop die vier en twintig ouderlinge in wit klere sit. Hulle het goue krone op hul koppe as teken van hul heersersposisie. Hulle sit egter hul krone voor God neer om daarmee te erken dat hulle al hul gesag van God ontvang het: "The honor given them is freely returned to the One who alone is worthy of universal honor" ${ }^{42}$. In teenstelling met die vier lewende wesens rig die vier en twintig ouderlinge hul lof direk aan God. Hul lof is dan ook eerder gebaseer op God se dade in die skepping as op sy Goddelike eienskappe. Hulle is voortdurend besig om God te loof en Hom te aanbid op grond van wat Hy doen (Op 4:8; 11:17,18).

God se waardigheid ( $\dot{\alpha} \xi \operatorname{los} \varepsilon \hat{i})$ word op tipies politiese wyse omgesit in aanbiddingswaardigheid. In die destydse Romeinse Ryk is die keiser begroet met die woorde " $\dot{\alpha} \xi \iota_{\text {Lo }}$ ¿i". Dan is bepaalde eienskappe aan hom toegedig. In Openbaring word dit gebruik om bepaalde eienskappe wat uniek en aanbiddingswaardig is, aan God toe te skryf ${ }^{43}$. Vir die Christene van destyds was die keiseraanbidding 'n geweldige probleem. Hulle kon en wou alleen die Een wat op die hemelse troon sit, aanbid; Hy alleen is waardig om alle heerlikheid, eer en mag te ontvang. Alle aanbidding word gebaseer op en gefundeer in die feit dat God alles geskep het en dat alles deur sy wil ontstaan het.

Die wyse waarop die ouderlinge aan God lof en eer toebring, is daarop gemik om die mens opnuut onder die indruk te bring van wie God 
werklik is. Die mens bestaan nie maar net nie. As skepsel van God moet die mens homself in perspektief sien, naamlik in verhouding tot sy Skepper, die Almagtige: "Finally, Johns vision draws the reader into worship of the One who alone is holy and who alone is Creator..."44.

Deur middel van die opeenstapeling van Godsname en Godsbeskrywings (Op 4:8b, 11; 11:17; 19:6b) wil Johannes sy lesers begelei om God te vereer en te aanbid. Hierdie uitsprake dien terselfdertyd ook 'n polemiese doel: God alleen is die ware, heilige, Skepper-God en Hy alleen verdien om aanbid te word. Naas Hom is daar geen God nie.

God se lof word in steeds wyerwordende konsentriese sirkels besing. Sy aanbidding kring uit van die vier lewende wesens, die vier en twintig ouderlinge, die ontelbare menigte engele (Op 5:11) en die oorwinnaars (Op 15:2) na die groot menigte (Op 19:1,6) om dan weer terug te keer na die sentrum van aanbidding, naamlik die troon vanwaar die harde stem kom (Op 19:5). Die stem vanaf die troon roep by wyse van 'n exhortatio almal op om God se lof te besing. In hoofstuk 5 word die vier lewende wesens se taak om God sonder onderbreking te aanbid, volvoer wanneer die ganse skepping by die aanbiddingsproses betrokke raak (Op 5:13) en kan hulle met reg sê: "Amen". Die grand finale breek aan wanneer alles en almal ja, die ganse kosmos in aanbidding buig voor God en sy lof ongedifferensieerd besing.

\subsection{Die Christologie van Openbaring soos vervat in die himnes}

Teoloë het in die verlede dramaties verskil in hul siening ten opsigte van Christus se rol in Openbaring. Luther was van mening dat Christus nie in Openbaring enige funksie vervul nie. Calvyn het dit nie nodig gevind om 'n kommentaar oor Openbaring te skryf nie. Moderne teoloë soos Bultmann en Dodd het ook nie waardering vir die Christologie in Openbaring nie 45 . Ons tref egter sonder twyfel 'n hoë Christologie in Openbaring aan wat onderskei kan word in die persoon en in die werk van Christus onderskeidelik ${ }^{46}$.

In Openbaring 5 word daar by wyse van 'n visioen asook 'n himne en in hoofstuk 7 by wyse van nog 'n lied aangetoon op welke besondere wyse Johannes vir Jesus Christus met God identifiseer. Johannes vleg hierdie oortuiging en belydenis soos 'n goue draad dwarsdeur Openbaring. Johannes se bedoeling is om aan te toon dat Jesus Christus tot die volheid van God se ewige wese, bestaan en handelinge behoort ${ }^{47}$. Weens die trinitaries-christologiese aard van die boek word talle eienskappe en handelinge van Christus dan ook in een asem met dié van God genoem. 
Net so word die benaminge wat vir die God gebruik word, ook vir die Lam gebruik48.

\subsubsection{Die persoon van Jesus Christus - Titels}

\subsubsection{Christus}

Die benaming "Christus" word enersyds verbind met die aardse Jesus, sy lyding en sterwe aan die kruis ${ }^{49}$. Andersyds verbind die Christus-titel die offer van Jesus aan die kruis met sy unieke hoëpriesterskapso. Die Christus-titel dien dus ook as benaming vir die verhoogde Here. Hy is die Een wat God se doel met sy skepping volvoer het (Op 1:12-20; 14:14-16; 19:11-21). Hy regeer oor die kerk (Op 2-3), oor die kosmos (Op 4-11) en is in beheer van die gang van die geskiedenis $\left(O p\right.$ 12-22) ${ }^{51}$. Nêrens in die Nuwe Testament word die verheerlikte Christus so duidelik geteken as in Openbaring nie 52 .

\subsubsection{Leeu uit die stam van Juda}

Die benaming "Leeu uit die stam van Juda" herinner aan Genesis 49:9-10, waar Juda as ' $n$ jong leeu beskryf word. In Genesis is dit 'n simbool van $\mathrm{krag}$, oorwinning en verstand 53 . In Openbaring toon dit aan dat die Lam die vervulling van die Ou-Testamentiese messiaanse verwagting is.

\subsubsection{Afstammeling van Dawid}

Hierdie titel verwys na Jesaja 11:1,10. Daar lees ons van 'n takkie wat sal uitspruit uit die stam van Isai en 'n loot uit sy wortels wat sal vrug dra. Johannes wil by wyse van die Ou-Testamentiese titels wat op Jesus van toepassing gemaak word, aantoon dat die beloftes van God in Hom vervul is ${ }^{54}$.

\subsubsection{Die Lam}

Die "Leeu uit die stam van Juda" en die "Afstammeling van Dawid" roep "n sterk militaristiese en nasionalistiese beeld op, wat Johannes herinterpreteer na aanleiding van wat hy sien, naamlik dat dit die Lam is wat die oorwinning verseker. Deurdat Johannes hierdie kontrasterende begrippe teenoor mekaar afspeel, skep hy 'n unieke simbool van oorwinning by wyse van Christus se offerdood: "The Messiah has certainly won a 
victory, but he has done so by sacrifice..." 55 . Die dawidiese messias se oorwinning word dus beskryf in terme van die besondere bydrae en simboliese waarde van die Lam en laasgenoemde word weer beklemtoon, omdat sy offerdood die oorwinning oor die bose verseker het. Die Lam is dus beide die paaslam én die magtige regeerder. Die simboliese waarde van die Lam wat geslag is, het nie minder waarde as die regerende rol van die Lam nie. Christus se lydende getuienis en offerdood is juis die sleutelgebeure in God se oorwinning oor die bose en die vestiging van God se koninkryk op aarde.

Christus word enersyds voorgestel as die Een wat vir almal gesterf het en andersyds as die magtige Een deur wie God se eskatologiese heerskappy in vervulling gaan. God as die ewige, transendente God het alles voorafgegaan en sal ook alles verbygaan as die oorsprong en eskatologiese doelwit van die ganse skepping. Dit is nie bloot 'n vae hoop en 'n onseker verwagting nie, maar ' $n$ sekere en vaste wete, aangesien God se heerskappy finaal en sigbaar aangebreek het in Christus. Die implikasie van hierdie woorde is verreikend. Daarmee wil Johannes aantoon dat Christus en God een is ${ }^{56}$.

\subsubsection{Die kwaliteite waaroor die Lam beskik}

Al die kwaliteite wat daar in Openbaring 5 aan die Lam toegeskryf word en aan die Lam en aan God gesamentlik in hoofstuk 7, dien as heenwysings na God se mag en oorwinningskrag wat in Jesus se woorde en dade sigbaar geword het. Hierdie kwaliteite wat aan die Lam toegeskryf word, is nie bloot eienskappe waarvoor die Lam gereed is om te ontvang nie, maar kwaliteite waaroor $\mathrm{Hy}$ reeds beskik ${ }^{57}$.

Die $\delta u ́ v \alpha \mu \iota \varsigma$ van die Lam is sigbaar in die oorwinning wat Hy oor die magte van die bose behaal het en word begrond in sy offerdoodss.

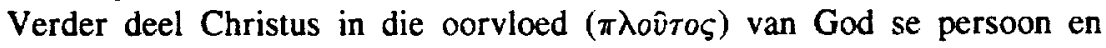

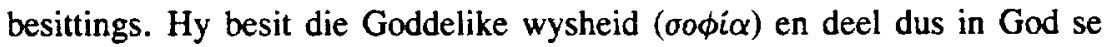
alwysheid. Hy is sterk (ioxús), want hy het die oorwinning oor die dood en oor die magte van die bose behaal.

Christus besit net soos God heerlikheid $(\delta \dot{\xi} \xi \alpha)$, eer $(\tau \iota \mu \dot{\eta})$ en lof ( $\varepsilon \dot{\nu} \lambda o \gamma i \alpha$ ). Johannes wil dus aantoon dat Christus op dieselfde vlak as God bestaan en as sodanig geëer moet word. Christus beskik net soos God oor glorie, majesteit en mag. Soos wat dit die mens se hoogste roeping is om God te aanbid, moet lofprysing en doksologieë ook aan Christus toegebring word. Net soos in die aanbidding van God word Christus/Lam geprys vir wie $\mathrm{Hy}$ is en vir wat $\mathrm{Hy}$ gedoen het. Met ander woorde $\mathrm{Hy}$ is al ons lof waardig op grond van sy persoon en op grond van sy dade ${ }^{59}$. 


\subsubsection{Middelpunt van aanbidding}

Waar God in hoofstuk 4 die middelpunt van aanbidding was, word die Lam as gevolg van sy opstanding en oorwinning oor die bose en die dood die middelpunt van aanbidding in Openbaring 5 . Net soos met die aanbidding van God, kniel die vier lewende wesens en die vier en twintig ouderlinge ook voor die Lam neer in aanbidding. Hulle sing 'n nuwe lied tot eer van die Lam, omdat daar ' $n$ nuwe verbond tot stand gekom het as gevolg van Jesus Christus se sterwe en opstanding: “The Lamb's saving work has created a new situation and this elicits a new outburst of praise" 60 .

Wanneer die Lam aanbid word, kring die bewondering ook in konsentriese sirkels uit soos met die aanbidding van Hom wat op die troon sit. Eers het net die vier lewende wesens en die vier en twintig ouderlinge die Lam aanbid. Dan besing die engele (Op 5:11) en daarna die ganse skepping (Op 5:13) die Lam se lof.

Die menigte engele word nie in hoofstuk 4 vermeld nie. Dis asof die skrywer hul bestaan doelbewus verswyg om sodoende 'n hoogtepunt te bereik met die aanbidding van die Lam. Die klimaks word bereik wanneer die ganse skepping aan die Lam en aan God lof, eer en heerlikheid toebring en hul $\mathrm{krag}$ besing. Die universele aard van die Lam se oorwinning eis 'n universele lofuiting ${ }^{61}$.

\subsubsection{Die Lam en God is gelykwaardig}

In Openbaring 5:13b stel Johannes vir Christus onomwonde aan God gelyk. Johannes probeer nie om vir Christus voor te stel as 'n tweede voorwerp van aanbidding naas God nie, maar hy wil aantoon dat Christus in God se glorie deel en ingesluit is in die goddelikheid van Hom wat op die troon sit ${ }^{62}$.

Benewens Openbaring is daar ander aanduidings (2 Tim 4:18; 2 Petr 3:18) dat Christus deur die vroeë kerk aanbid is. Bauckham ${ }^{63}$ lê klem op die feit dat die aanbidding van Christus 'n ontwikkeling binne die JoodsChristelike monoteïsme was. In Openbaring word God op monoteïstiese wyse aanbid (Op 22:9). Wanneer Jesus dus aanbid word, dien dit as bewys dat $\mathrm{Hy}$ as God erken word: "That the Lamb is worshipped is evidence of his full divinity, for in this book God alone is worshipped"64.

Hierdie gelykwaardigheid van Christus aan God is onder andere sigbaar uit die selfuitsprake van God en Christus. Beide Christus en God 
word die "Alfa en Omega, die Eerste en Laaste" genoem (Op 1:8, 17; $21: 6 ; 22: 13)$. Tweedens is dit sigbaar in die feit dat Johannes Christus voorstel as die Een, wat deel het aan God se wese en bestaan. Derdens word beklemtoon dat God en die Lam oor dieselfde kwaliteite beskik. In die vierde plek loop die beklemtoning dat al die eer, heerlikheid en lof aan beide Christus en aan God toekom, soos 'n goue draad deur Openbaring.

Met al hierdie uitsprake wil Johannes beklemtoon dat Christus deel het aan God se ewige bestaanswyse. Deur hierdie uitsprake word die eksklusiewe, monoteïstiese aard van die teks beklemtoon. "There cannot be the slightest doubt that the Lamb is to be reckoned with God and as God ${ }^{65}$.

By wyse van die himnes in Openbaring bied Johannes aan die gelowiges die geleentheid om "die Here van die heersers en die Koning van die konings" (Op 17:13; 19:16b) te aanbid en sy lof te besing. Die wêreld en die gang van die geskiedenis is nie aan die noodlot uitgelewer nie, maar veilig in die hande van 'n liefdevolle Vader en genadige Redder, wat gesterf het vir almal wat in Hom glo ${ }^{66}$.

\subsubsection{Dade van die Lam}

Die waardigheid van die Lam word net soos die waardigheid van God in hoofstuk 4 besing. Dieselfde toeskrywing van waardigheid aan die Lam en aan God, toon die verdiepte Christologie van Openbaring aan. Die waardigheid van die Lam is egter nie gebaseer op sy wese alleen nie, maar veral op sy groot dade van redding, verlossing en versoening. Hy is waardig om die boek te neem en die seëls daarvan oop te maak om drie redes: Hy is geslag; Hy het mense vir God losgekoop; Hy het hulle 'n koninkryk en priesters vir God gemaak.

\subsubsection{Die Lam is geslag}

Die waardigheid van die Lam hou direk verband met sy versoeningsdood: "He is worthy precisely because he was slain"67. Die versoening by wyse van 'n bloedoffer kom ook in die Ou Testament voor. In Openbaring simboliseer hierdie metafoor dat Jesus Christus geslag is om mense van die slawerny van sonde te verlos net soos die paaslam geslag is as simbool van die bevryding uit slawerny in Egipte.

\subsubsection{Die Lam het mense vir God losgekoop}

Christus se bloed het gedien as betaalmiddel, waarmee $\mathrm{Hy}$ mense uit die mag van die bose losgekoop het om nou aan God te behoort. Die twee 
woorde $\tau \hat{\varphi} \theta \varepsilon \hat{\varphi}$ (Op 5:9c) speel 'n belangrike rol. Dit wil beklemtoon dat die heiliges aan God behoort. Christus se offerdood het mense uit elke volk, stam, taal en nasie van sonde bevry (Op 5:9-10) om hulle tot kinders van God te maak. In teenstelling met die partikularisme van die Judaïsme, vertoon die kerk van Christus 'n universele karakter.

\subsubsection{Die Lam het hulle 'n koninkryk en priesters vir God gemaak}

Die doel van Christus se loskoping is om gelowiges in staat te stel om te heers as konings en om diens te doen as priesters. Sodoende kan gelowiges die oorwinning van die Lam op elke lewensterrein uitbasuin en terselfdertyd as mede-oorwinnaars in Christus leef68. Hierdeur vervul Christus die belofte van God in Eksodus 19:5: “As julle My gehoorsaam en julle aan my verbond hou, sal julle uit al die volke my eiendom wees, 'n koninkryk wat $\mathrm{My}$ as priesters dien en 'n gewyde nasie". Almal wat tot God se koninkryk in Christus behoort, het direkte toegang tot God en is dus priesters, wat 'n lewe van aanbidding lei.

\section{DIE HIMNES VAN OPENBARING HET OOK 'N BOODSKAP VIR VANDAG}

Bepaalde tye bied aan die kerk en die prediker geleentheid om prominensie te verleen aan bepaalde Bybelboeke. Augustinus het deur ' $n$ studie van Genesis probeer vasstel hoe die stad van God vorm kan aanneem in 'n dekadente, rommelbestrooide Romeinse Ryk. In die twaalfde eeu het Bernard met behulp van Hooglied probeer om ware, volwasse liefde te illustreer in 'n tyd toe erotiek hoogty gevier het. Luther het gesoek na die eenvoud en deursigtigheid van die evangelie en dit gevind tussen die lyne van Romeine ${ }^{69}$. Die twintigste eeu is tans besig om op sy laaste bene te staan en meer as ooit het Openbaring betekenis vir die mens van vandag.

Te midde van uitstekende fasiliteite, mediese versorging, intellektuele stimulasie en relatiewe finansiële welvaart is die mens van vandag bekommerd, eensaam en onseker oor God. Hierin bied Openbaring vir ons 'n antwoord: Openbaring is geskryf om die goeie nuus aangaande Jesus Christus aan mense in onsekere, kultuurverwronge omstandighede te bring. In Johannes se tyd was die hoorders en lesers van hierdie boek uitgelewer aan godsdienstige- en politieke vervolging: "They were experiencing a trivialization of the gospel by gossip, and a deflection of the gospel by trouble" 70 . Openbaring bied aan God se kinders die versekering dat hulle sy eiendom is en dat hulle veilig is in sy beskerming. 
By wyse van die liedere in Openbaring stel Johannes sy lesers op hoogte van God se mag, posisie en status as Koning, Regter, Redder en almagtige Skeppergod. Openbaring skilder vir Christus as die Lam, wat in sy liefdevolle uitreiking na die mensdom die finale oorwinning oor die bose en die dood behaal het. Hy is nie alleen die Gestuurde van God nie, Hy is self ook God.

Die liedere in Openbaring wil gelowiges daarop wys dat alhoewel God nie op aarde erken word as die Ewige en Almagtige nie, Hy dit sonder twyfel is. God sit op sy troon en die antitese tussen die historiese omstandighede op aarde en die hemelse werklikheid moet die gelowige mens nie ontmoedig nie, maar juis bemoedig, want die hemelse werklikheid gaan binnekort ook op aarde realiseer. Die boodskap van bemoediging wat daar van Openbaring uitgaan, word gekonkretiseer by wyse van 'n imperatief. Hierdie liedere wat destyds tydens die eredienste gesing is, kan vandag ook weer gesing word om die hedendaagse mens opnuut te vul met hoop en verwagting. Van die eerste tot die laaste bladsy van Openbaring word die leser blootgestel aan toneel op toneel van toegewyde aanbidding aan God en die Lam deur almal wat in die hemel aanwesig is. Ons wat so maklik verward en opgeslurp raak in en deur ons omstandighede, word opnuut opgeroep na die middelpunt en ware rede vir alle bestaan: "Aanbid God!” (Op 22:9).

\section{NOTAS:}

1 Smelik het 'n studie van die himne in Jona 2 gemaak en tot die gevolgtrekking gekom dat die lied in Jona die teologie van die boek bevat. Vergelyk K A D Smelik, "Het staat er niet voor niets", Interpretatie (Januarie 1995) 12-13.

2 D R Carnegie, Worthy is the lamb: the hymns in Revelation. Christ is the Lord: Studies in Christology presented to Donald Guthrie, Leicester 1982, 244-245.

3 D E Aune, "The Apocalypse of John and the problem of genre", Semeia 36, (1986), 66-96.

4 Carnegie, $a w, 246$.

5 Camegie, $a w, 243-256$.

6 R P Martin, "Hymns in the NT", The Imternational Standard Bible Encyclopedia 11 (1982), 788-790.

7 In Daniël 7 kom daar in die visioen oor die vier koninkryke 'n himne voor waarin alle mag van die diere weggeneem word en aan die "seun van die mens" gegee word.

8 IV Esra 8:19-20 bevat ook 'n lied waarin God se grootheid besing word: "O Lord that dwellest eternally, whose are the highest heavens, whose chambers are in the air, whose throne is beyond imagination, whose glory is inconceivable; before whom (heaven's) hosts stand trembling...".

9 J H Barkhuizen, "Himni Christiani", Hervonnde Teologiese Studies Supplement 1 (1989), 11. 
Barkhuizen, $a w, 11$.

11 Barkhuizen, $a w, 13$.

12 J Kroll, Die Christlichen Hymnodik bis zu Klemens von Alexandreia, Darmstadt 1968, 10-11.

13 Barkhuizen, $a w, 14$.

14 Barkhuizen, $a w, 14$.

15 Barkhuizen, $a w, 14$.

16 R Bauckham, New Testament Theology: The theology of the book of Revelation, New Britain 1993, 23.

17 Bauckham, $a w, 24$.

18 M A Harris, The literary function of hymns in the Apocalypse of John, Ann Arbor 1989, 240.

19 L Goppelt, Theology of the New Testament Vol. 2: The variety and unity of the Apostolic witness to Christ, Grand Rapids 1982, 185.

20 B J Malina \& R L Rohrbauch, Social science commentary on the Synopric Gospels, Minneapolis 1992, 80.

21 R H Mounce, The Book of Revelation (NICNT), Grand Rapids Michigan 1977, 288.

22 Bauckham, $a w, 34$.

23 C Brown, The International Dictionary of New Testament Theology, (Volume 2), Cumbria 1992, 45.

24 Bauckham, $a w, 27$.

25 Bauckham, $a w, 52$.

26 Bauckham, $a w, 48$.

27 Mounce, $a w, 172$.

28 Mounce, $a w, 172$.

29 Mounce, $a w, 77$.

30 Bauckham, $a w, 40$.

31 Bauckham, $a w, 44$.

32 Bauckham, $a w, 14$.

33 L Morris, Revelation (Tyndale New Testament Commentaries), Leicester 1990, 149.

34 Bauckham, $a w, 52$.

35 Bauckham, $a w, 34$.

36 Brown, $a w, 614$.

37 Bauckham, $a w, 31$.

38 J M Ford, Revelation: Introduction, translation and commentary, New York 1975, 257.

39 Morris, $a w, 183$.

40 J A du Rand, Kyk, die Koning kom!, Vereeniging 1992, 105.

41 Bauckham, $a w, 33$.

42 Mounce, $a w, 139$.

43 Mounce, $a w, 140$.

44 Bauckham, $a w, 45$.

45 D Guthrie, The relevance of John's Apocalypse, Devon 1992, 37.

46 Bauckham, $a w, 54$.

47 Bauckham, $a w, 57$. 
48 I A du Rand, "Die Openbaring van Johannes: Inleiding en Teologie, in: Du Toit, A B (red), Handleiding by die Nuwe Testament Band VI, Pretoria 1988, 219-314.

49 Goppelt, $a w, 186$.

$50 \quad$ Du Rand, $a w, 1988,285$.

51 J A du Rand, Johannese perspektiewe, Deel 1, Pretoria 1990, 266.

52 R H Charles, A critical and exegetical commentary on the Revelation of St. John, (Volume 2), Edenburgh 1971, cxi.

53 J A du Rand, Want die einde is naby, Kaapstad 1986, 76.

54 Du Rand, $a w, 1986,76$.

55 Bauckham, $a w, 74$.

56 G R Beasley-Murray, The book of Revelation, London 1974, 189.

57 Mounce, $a w, 150$.

58 Brown, $a w, 604$.

59 Brown, $a w, 47$.

60 Morris, $a w, 96-97$.

61 Mounce, $a w, 150$.

62 Bauckham, $a w, 60$.

63 Bauckham, $a w, 61$.

64 Morris, $a w, 96$.

65 Morris, $a w, 99$.

66 Morris, $a w, 100$.

67 Mounce, $a w, 148$.

68 Du Rand, $a w, 1986,79$.

69 E H Peterson, "Learning to worship from Saint John's Revelation: as we encounter an end to an era we need the book at the end of the Bible", Christianity Today 35/28 (1991), 23.

70 Peterson, $a w, 24$. 